\title{
Impacts of Andean uplift on the Humboldt Current system: A climate model sensitivity study
}

\author{
Pierre Sepulchre, ${ }^{1,2}$ Lisa C. Sloan, ${ }^{1}$ Mark Snyder, ${ }^{1}$ and Jerome Fiechter ${ }^{3}$ \\ Received 1 August 2008; revised 4 June 2009; accepted 14 August 2009; published 17 December 2009.
}

[1] Using both an atmospheric global circulation model and a regional oceanic model, we assess the impact of the Andes uplift on the Humboldt Current system (HCS). With three topographic scenarios for the Andes, we show that the uplift played a crucial role in shaping the lower troposphere dynamics over the Pacific Ocean and in turn affected the physical characteristics of the system. Our results show that the uplift has triggered a marked southward shift of the HCS, changing the latitudinal position of coastal upwelling areas as well as the strength of the South Pacific gyre. Our oceanic modeling experiments show that the latitudinal pattern of sea surface temperatures is dramatically modified with reduced Andes, with anomalies reaching up to $3^{\circ} \mathrm{C}$. We discuss the feedbacks of these changes on South American climate as well as the potential onset of an altitudinal threshold that would have had triggered these changes.

Citation: Sepulchre, P., L. C. Sloan, M. Snyder, and J. Fiechter (2009), Impacts of Andean uplift on the Humboldt Current system: A climate model sensitivity study, Paleoceanography, 24, PA4215, doi:10.1029/2008PA001668.

\section{Introduction}

[2] Constraining the interactions between climate evolution and tectonic uplift during the Cenozoic is an ongoing challenge in geosciences [Hay et al., 2002]. In this study, we focus on the Humboldt Current system (hereafter HCS) and how it might be affected by changes in atmospheric dynamics and Miocene uplift of the Andes.

[3] The HCS refers to the oceanic system in the eastern South Pacific, wherein subantarctic cold surface waters flow equatorward off the coast of South America, with a meridional extent of more than $4000 \mathrm{~km}$. Though it corresponds roughly to the eastern part of the South Pacific gyre, this system is complex and can be subdivided in several surface currents. These currents are characterized by semipermanent upwelling, which results in the coastal waters off of Peru and Chile having important marine biomass productivity and yield [Alheit and Bernai, 1992; Caviedes and Fik, 1992]. The combination of upwellings and advection of subantarctic waters creates a long "cold tongue" between $\sim 40^{\circ} \mathrm{S}$ and $\sim 5^{\circ} \mathrm{S}$ off of South America [Thiel et al., 2007]. These cold sea surface temperatures (hereafter SSTs) play a major role on South American hydrology and climate, and are considered to be one of the main factors to explain aridity of the adjacent western coast of South America, rather than a rain shadow effect linked to the Andes uplift [Houston and Hartley, 2003]. Of interest to the Earth science community is how the HCS has evolved over the Neogene, and is its evolution independent of other forcing factors such as tectonics.

\footnotetext{
${ }^{1}$ Department of Earth and Planetary Sciences, University of California, Santa Cruz, California, USA.

${ }^{2}$ Laboratoire des Sciences du Climat et de l'Environnement, IPSL, CEA, UVSQ, CNRS, Gif-sur-Yvette, France.

${ }^{3}$ Department of Ocean Sciences, University of California, Santa Cruz, California, USA.

Copyright 2009 by the American Geophysical Union. 0883-8305/09/2008PA001668
}

[4] The dynamics of the HCS are strongly linked to surface wind patterns. Winds from the southeastern Pacific Subtropical Anticyclone (hereafter the South Pacific High (SPH)), bounded to the north by the Inter Tropical Convergence Zone (ITCZ) and to the south (south of $42^{\circ} \mathrm{S}$ ) by a strong zonal eastward flow, provide vorticity and define the large-scale surface structure of the South Pacific gyre. In addition, the equatorward winds blowing along the Chilean and Peruvian coasts are due to both the structure of the SPH and to the massive topographic barrier of the Andes that contributes to their deflection along the coast [Xu et al., 2004].

[5] The Andes extend for more than $5000 \mathrm{~km}$ along the western coast of the South American continent. The Northern Hemisphere Andes are composed of three cordilleras situated between $1^{\circ} \mathrm{N}$ and $8^{\circ} \mathrm{N}$. In this region, the highest elevation is approximately $3500 \mathrm{~m}$. The cordillera is wider in the Southern Hemisphere, especially in its central part at approximately $20^{\circ} \mathrm{S}$, with a $700 \mathrm{~km}$ west-east (hereafter zonal) extension. Uplift history is not well constrained for the entire range of the Andes, but some information can be found concerning the different subdomains, showing that most of the uplift occurred during middle to late Miocene (the last 15 millions of years) [Picard et al., 2008]. There is general consensus [Gregory-Wodzicki, 2000; Lamb et al., 1997] that the Altiplano had attained an elevation of no more than $1900 \mathrm{~m} 10.7$ millions of years ago (hereafter Ma). Paleoaltimetry suggests an abrupt surface uplift of $\sim 2.5-3.5 \mathrm{~km}$ between 10.3 Ma and 6.8 $\pm 0.4 \mathrm{Ma}$ [Garzione et al., 2006, 2008]. River profiles on the western flank of the Altiplano suggest a relative surface uplift of at least $1 \mathrm{~km}$ after $10 \mathrm{Ma}$ [Hoke et al., 2007].

[6] Continental aridity records as well as isotopic measurements from marine vertebrate fossils invoke the existence of an "ancestral Humboldt current" during the Miocene [Alpers and Brimhall, 1988; Amiot et al., 2008]. HCS evolution over the Cenozoic has been assessed since the late 80s with drillings off Peru (ODP Leg 112; see Summerhayes 
Table 1. Summary of the Boundary Conditions Used for the Three LMDz4 Runs and the Two ROMS Experiments

\begin{tabular}{|c|c|c|c|}
\hline & CTL & LOWANDES & NOANDES \\
\hline $\begin{array}{l}\text { LMDz4 } \\
\text { boundary conditions }{ }^{\mathrm{a}}\end{array}$ & $\begin{array}{l}\text { Modern topography, interpolated } \\
\text { on LMDz grid; maximal altitude, } \\
4907 \mathrm{~m} \text { above sea level (asl) }\end{array}$ & $\begin{array}{l}\text { Reduced topography over } \\
\text { the Andes; maximal altitude, } \\
2720 \mathrm{~m} \text { asl }\end{array}$ & $\begin{array}{c}\text { Reduced topography over } \\
\text { the Andes; maximal altitude, } \\
296 \mathrm{~m} \text { asl }\end{array}$ \\
\hline $\begin{array}{l}\text { ROMS } \\
\text { boundary conditions }\end{array}$ & $\begin{array}{l}\text { RCTL, monthly mean momentum, } \\
\text { heat, and freshwater fluxes } \\
\text { from CTL outputs }\end{array}$ & & $\begin{array}{l}\text { RNOANDES, monthly mean momentum, } \\
\text { heat, and freshwater fluxes } \\
\text { from NOANDES outputs }\end{array}$ \\
\hline
\end{tabular}

et al. [1992] for a synthesis). Although focus was put on Pliocene and Pleistocene epochs, studies of foraminifera fauna have suggested changes in water temperatures during the Miocene [Ibaraki, 1990]. More recently, studies from ODP Leg 202 have shown a decrease in SSTs since 7 Ma off Chile [Tiedemann et al., 2007].

[7] Mechanisms driving HCS evolution involve interactions between global climate changes and paleogeography (uplifts and changes in gateways configurations). Atmospheric pCO2 levels were likely close to preindustrial values during the Miocene [Pagani et al., 2005] and can hardly be considered as a forcing factor for HCS evolution during the Miocene. Continental drift includes the opening of the Drake passage at $\sim 28 \mathrm{Ma}$ [Barker and Thomas, 2004], that likely impacted the HCS before the Andes uplift. Closure of the Central American seaway at ca. 3 Ma [Bartoli et al., 2005] might have played a role in intensifying the HCS after the main Andes uplift, as colder temperatures are recorded in late Neogene marine sequences of Ecuador, Peru and northern Chile [Tsuchi, 1997].

[8] Here we wish to revisit the impact of the Andes uplift on the HCS by quantifying atmospheric and oceanic dynamics changes linked to variations of topography. Our strategy is to design numerical sensitivity experiments to assess the impact of the Andes uplift on the HCS. We hypothesize that the Andes had a strong influence on atmospheric dynamics and in turn on ocean circulation. To test this hypothesis, we use two different high-resolution modeling tools. First we quantify the impact of the uplift on atmospheric dynamics above the Pacific ocean with a high-resolution atmospheric model. Then we assess the oceanic response to these atmospheric modifications with a regional ocean model.

\section{Methods}

\subsection{Experimental Design}

[9] In this paper we use two types of model to assess how uplift of the Andes affected the HCS. A model of atmospheric circulation is used to investigate how changes in Andes elevation altered lower troposphere wind fields. As we aim at understanding how altered wind fields have in turn changed surface characteristics of the HCS, we developed a second set of numerical experiments, using an ocean basinscale model.

[10] To assess our first point, we use the three-dimensional atmospheric global circulation model (AGCM) LMDz4, developed at Laboratoire de Météorologie Dynamique, Paris [Hourdin et al., 2006]. For this study, we use a configuration with 144 grid points in longitude, 108 in latitude and 19 vertical layers, with the first four layers contained within the first kilometer above the surface. LMDz4 has a stretchable grid which allows increased spatial resolution over a defined region. In our case, we set this zoom feature over South America to get a resolution of ca. $140 \mathrm{~km}$ over the continent and the adjacent eastern Pacific, which is a good compromise between reasonable computing time and a spatial resolution that adequately represents the main features of South American topography. Prescribed visible albedo and roughness length from present vegetation cover are used. Here we employ a typical sensitivity study approach, designing a control and experimental cases, with boundary conditions in each case differing by only one parameter (Table 1). The parameter tested is topographic structure of the western South American continent.

[11] The control experiment (CTL) is a preindustrial run, with boundary conditions kept at preindustrial values (Table 1). Topography is derived from a $10 \mathrm{~min}$ U.S. Navy data set and spatially interpolated to the model grid. This interpolation leads to a loss of information concerning altitude maxima over the Andes (4907 $\mathrm{m}$ for CTL, compared to 5486 in the topographic data set). This loss is important between the equator and $10^{\circ} \mathrm{N}$, where the Andes are a very narrow mountain range. However, the relief representation is still reliable, as the narrow Columbian cordilleras are distinguishable (Figure 1a). A second experiment, referred to as NOANDES, has reduced altitude over the Andes. Because we wanted to retain the present-day topography of the eastern part of South America, while avoiding creating artificial topographic artifacts such as step-like effects between reduced and elevated areas, we smoothly reduced the altitude with a linear function (Figure 1c). Maximum altitude, situated over the Altiplano, is reduced to ca. $296 \mathrm{~m}$. Elevations are ca. $240 \mathrm{~m}$ over the Central Andes, and ca. $150 \mathrm{~m}$ over the Columbian Andes. Southward, topography ranges from $250 \mathrm{~m}\left(3500 \mathrm{~m}\right.$ in CTL run) at $30^{\circ} \mathrm{S}$ to $70 \mathrm{~m}(1000 \mathrm{~m}$ in CTL run) at $50^{\circ} \mathrm{S}$. A third experiment, referred as LOWANDES, has been configured with an intermediate elevation between NOANDES and CTL. Maximum elevation for this last run is 2720 m over the Altiplano, Columbian Andes are $~ 1000-$ $1400 \mathrm{~m}$ high (Figure 1b). Each experiment was run for 15 years. We analyze seasonal averages made over the last thirteen years, as the two first years are extracted for spin-up.

[12] The ocean circulation model for the southeastern $\mathrm{Pa}-$ cific domain $\left(110^{\circ}\right.$ to $69^{\circ} \mathrm{W}$ and $50^{\circ}$ to $\left.5^{\circ} \mathrm{S}\right)$ is an implementation of the Regional Oceanic Modeling System (ROMS) [Haidvogel et al., 2000; Shchepetkin and McWilliams, 2005]. 
a

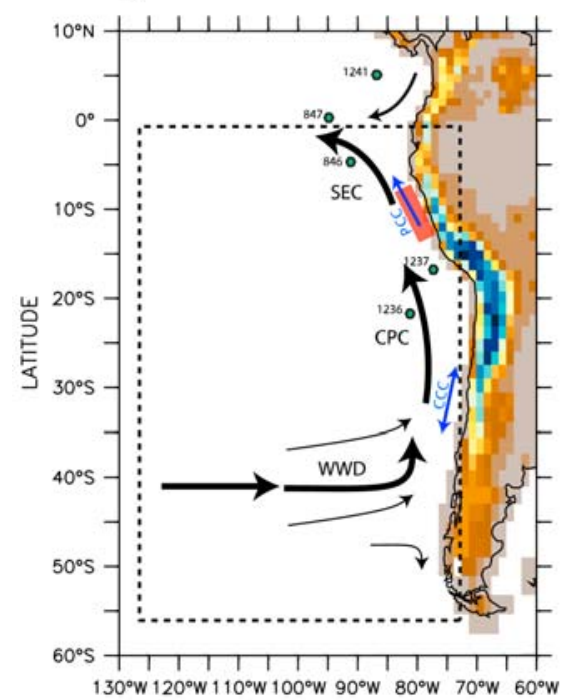

b

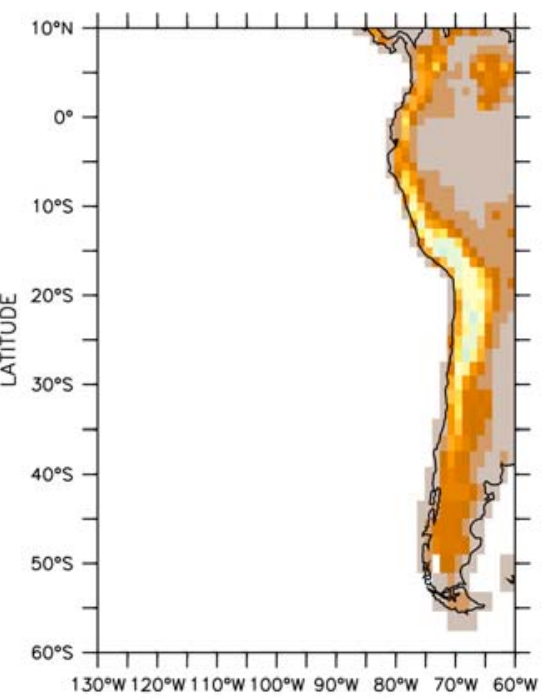

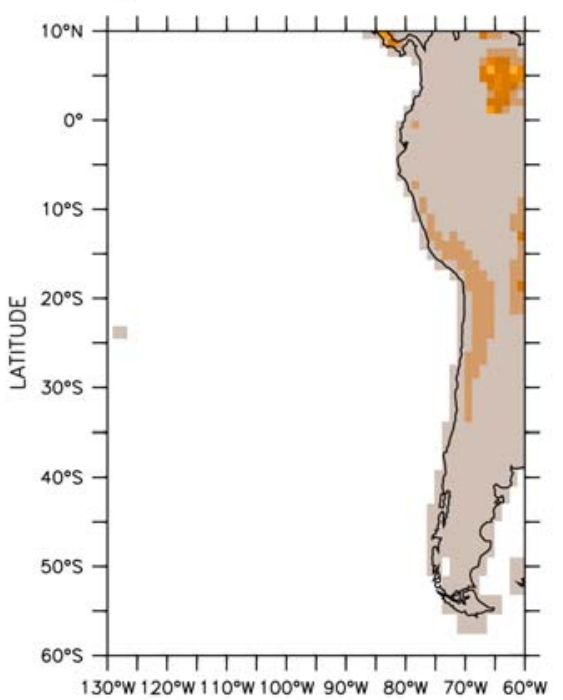

\begin{tabular}{c|c|c|c|c|c|c|c|c|c|c|c|c|c|c|c|c|c|c|}
\hline & & & & & & & & & & & & & & & & & & \\
0
\end{tabular}

Figure 1. (a) Relief as seen by LMDz4 for CTL experiment. Same for (b) LOWANDES and (c) NOANDES. Dotted square in Figure 1a represents the area considered in this study as the Humboldt Current system. Black arrows represent the main offshore currents, and blue arrows represent the coastal currents. Green symbols show the three sites from ODP Leg 202 that provide information about ante-Pliocene HCS evolution [Tiedemann et al., 2007]. Red-shaded area shows location of ODP Leg 112 drills discussed by Ibaraki [1990]. SEC, South Equatorial Current; PCC, Peru Coastal Current; CPC, Chile-Peru Current; CCC, Chile Coastal Current; WWD, West Wind Drift.

ROMS is a hydrostatic, primitive equation model that uses a terrain-following vertical coordinate and a split mode technique to efficiently solve for baroclinic and barotropic variables. The ROMS ocean circulation model provides a comprehensive and flexible framework for a wide range of applications, going from basin-scale [e.g., Curchitser et al., 2005] to regional-scale [e.g., Fiechter and Moore, 2009] simulations. The ocean circulation model is driven on all open boundaries by monthly climatological fields for temperature and salinity (World Ocean Atlas 2001, $1^{\circ} \times 1^{\circ}$ horizontal resolution [Conkright et al., 2002]), as well as geostrophic currents derived from the temperature and salinity fields assuming a level of no motion at $500 \mathrm{~m}$ depth. The surface forcing for the southeastern Pacific ocean circulation model is derived from the AGCM model in the form of monthly mean momentum, heat, and freshwater fluxes. Open boundary conditions and surface forcing are linearly interpolated at each time step between the monthly averaged values to guarantee smooth variations in time. The ROMS model grid has a horizontal resolution of $1 / 2^{\circ}$ and 30 nonuniform vertical levels, with clustering near the surface. The bottom topography mapped on the grid is based upon ETOPO2 (2 min gridded global relief data; http://www.ngdc.noaa.gov/ $\mathrm{mgg} /$ fliers/06mgg01.html) and smoothed to reduce the pressure gradient errors due to the terrain-following vertical coordinate. Here we forced ROMS with LMDz monthly averaged variables from CTL and NOANDES experiments.
The two ROMS experiments are further referred to as RCTL and RNOANDES.

\subsection{Wind Stress Calculation}

[13] As depicted by the analysis of satellite measurements for the 1979-2003 period [Chaigneau and Pizarro, 2004], the ageostrophic component of the HCS surface currents is important and thus the mean flow of the HCS is strongly dependent on surface winds. Consequently, studying the appropriate fields from the atmospheric dynamics gives a direct indication of the changes affecting the HCS [Bakun and Nelson, 1991; Bigg, 2003] both at the basin scale and at the regional scale (upwellings). We have calculated the wind stress fields from both experiments surface wind fields. The wind stress magnitude $(\tau)$ and its zonal $\left(\tau_{\mathrm{x}}\right)$ and meridional $\left(\tau_{\mathrm{y}}\right)$ components $\left(\mathrm{N} \mathrm{m}^{-2}\right)$ are calculated from the bulk formulation by Trenberth et al. [1990]. It is important to note that this formulation has been routinely used to compute wind stress from atmospheric climate models [Snyder et al., 2003]:

$$
\begin{gathered}
\tau=\rho \cdot C_{d} \cdot\|\vec{w}\|^{2} \\
\tau_{x}=\rho \cdot C_{d} \cdot\|\vec{u}\| \cdot\|\vec{w}\| \\
\tau_{y}=\rho \cdot C_{d} \cdot\|\vec{v}\| \cdot\|\vec{w}\|
\end{gathered}
$$

where $\rho$ indicates the density of surface air $\left(1.25 \mathrm{~kg} / \mathrm{m}^{3}\right), C_{d}$ is the dimensionless $10 \mathrm{~m}$ neutral drag coefficient over the 
ocean, which varies nonlinearly with wind speed. Here $u$ and $\mathrm{v}$ are the zonal and meridional wind velocity components $\left(\mathrm{m} \mathrm{s}^{-1}\right)$, respectively, and $\mathrm{w}$ is the wind speed magnitude $\left(\mathrm{w}=\left(\mathrm{u}^{2}+\mathrm{v}^{2}\right)^{0.5}, \mathrm{~m} \mathrm{~s}^{-1}\right)$. Negative (positive) values for $\tau_{\mathrm{x}}$ and $\tau_{\mathrm{y}}$ indicate westward and southward (eastward and northward) wind stress direction, respectively.

\section{Results}

\subsection{Comparing LMDz4 and NCEP: Present-Day Evaluation}

[14] Wind stress values calculated from the NCEP reanalysis [Kalnay et al., 1996] (NCEP Reanalysis Derived data provided by the NOAA/OAR/ESRL PSD, Boulder, Colorado, USA, from their Web site at http://www.cdc.noaa.gov) are analyzed and compared to CTL experiment in Figure 2. Between the equator and $30^{\circ} \mathrm{S}$, the northern branch of the $\mathrm{SPH}$ is characterized by strong easterlies, and wind stress values have a strong zonal component offshore and a strong meridional component (reaching up to $0.11 \mathrm{~N} \mathrm{~m}^{-2}$ in NCEP) along the coast (Figures $2 \mathrm{a}$ and $2 \mathrm{~b}$ ). Between $30^{\circ} \mathrm{S}$ and $50^{\circ} \mathrm{S}$, the pattern is reversed as winds from the southern branch of the SPH are westerlies. The simulated wind stress spatial pattern in CTL is consistent with the reanalysis. Wind stress values north to the equator are low, between 0.01 and $0.03 \mathrm{~N}$ $\mathrm{m}^{-2}$, consistent with NCEP values. Both NCEP and CTL show that the HCS wind stress pattern is characterized by (1) strong zonal components offshore, oriented westward north of $30^{\circ} \mathrm{S}$, eastward south of $30^{\circ} \mathrm{S}$, and (2) strong meridional components along shore, mainly northward and upwelling favorable, except south of $45^{\circ} \mathrm{S}$. This pattern varies seasonally, following the northward shift of the SPH.

[15] However, despite the large-scale good agreement between CTL and NCEP, there are also areas of mismatch within each subregion. The wind stress values are underestimated by up to $45 \%$ between $20^{\circ} \mathrm{S}$ and $10^{\circ} \mathrm{S}$, along the Chilean coast. Wind stress is also underestimated between $55^{\circ} \mathrm{S}$ and $50^{\circ} \mathrm{S}$ (by up to $40 \%$ ). These mismatches can be explained by looking at zonal (Figures $2 \mathrm{c}$ and $2 \mathrm{~d}$ ) and meridional (Figures $2 \mathrm{e}$ and $2 \mathrm{f}$ ) components of the modeled wind stress. The meridional wind stress (hereafter MWS) is underestimated between $15^{\circ} \mathrm{S}$ and $5^{\circ} \mathrm{S}$, explaining the overall underestimation depicted above. Our interpretation is that this mismatch is linked to the differences of the algorithms and resolution used in $\mathrm{LMDz}$ and NCEP reanalysis to calculate winds. Despite these differences, the seasonal shift in wind patterns, as well as the reliable spatial distribution of the wind stress patterns, is consistent enough to run sensitivity experiments.

\subsection{Changes in Wind Stress When Elevations of the Andes Are Reduced}

[16] Figures 3 and 4 illustrate the CTL values of wind stress and simulated wind stress anomalies (LOWANDES-CTL and NOANDES-CTL) between the LMDz4 experiments, for austral summer (January) and winter (July). These values have been filtered by a Student $t$ test $(\mathrm{P}$ value at 0.95 ) run over the 15 years of simulation, so that we analyze only values that are statistically significant. Below we discuss the LOWANDES and NOANDES cases results relative to the results of the control case.
[17] $\tau_{\mathrm{x}}$ anomalies depict an offshore strengthening of the westward wind stress in January between $5^{\circ} \mathrm{N}$ and $10^{\circ} \mathrm{S}$ (Figures $3 \mathrm{a}, 3 \mathrm{~b}$, and $3 \mathrm{c}$, region $\mathrm{A}$ ). This increase is simulated in both cases, but is stronger in the NOANDES case, reaching up to $+200 \%$ north to the equator. A decrease is simulated between $15^{\circ} \mathrm{S}$ and $30^{\circ} \mathrm{S}$ (Figure $3 \mathrm{c}$, region $\mathrm{B}$ ) in the NOANDES case only. The combination of this decrease to the south and this increase to the north corresponds to a northward displacement of the wind stress pattern in January. This displacement is weak in LOWANDES case whereas it is $\sim 4^{\circ}$ northward in NOANDES (Figures $3 \mathrm{~b}$ and $3 \mathrm{c}$ ). Similar to January, the July westward wind stress is increased, but $\sim 10$ degrees northward (Figures $3 \mathrm{~d}-3 \mathrm{f}$ ). $\tau_{\mathrm{x}}$ values are also amplified along shore between $10^{\circ} \mathrm{S}$ and $30^{\circ} \mathrm{S}$ in the NOANDES case. South to $30^{\circ} \mathrm{S}$, the eastward wind stress is increased in NOANDES $\left(+0.04 \mathrm{~N} \mathrm{~m}^{-2}\right.$ (Figure $3 \mathrm{f}$, region $\mathrm{C}$ )), whereas the increased observed in LOWANDES does not appear to be significant (Figure 3e, region $\mathrm{C}$ ).

[18] $\tau_{\mathrm{y}}$ anomalies (Figure 4) show that most changes of MWS occur along shore. Differences between LOWANDES and CTL (Figures $4 \mathrm{~b}$ and $4 \mathrm{e}$ ) are weak and consist mainly of a decrease of northward, upwelling favorable winds between $20^{\circ} \mathrm{S}$ and $30^{\circ} \mathrm{S}$ in July, and a small increase at the same latitudes in January. As for zonal wind stress, changes are more significant for NOANDES case (Figures 4c and 4f), with an increase of northward wind stress to the north (up to $+0.06 \mathrm{~N} \mathrm{~m}^{-2}(+60 \%)$ over restricted areas) and a decrease to the south. Again, this pattern is linked to a northward shift of the wind stress structure. South to $40^{\circ} \mathrm{S}$, the weak southward component (between $45^{\circ} \mathrm{S}$ and $55^{\circ} \mathrm{S}$ in CTL) is reduced to zero in NOANDES and LOWANDES.

[19] These observations are linked to an important reorganization of atmospheric dynamics when the Andes are reduced in elevation. Figure 5 shows January and July sea level pressure and surface wind fields for the three topographic scenarios.

[20] In January, a strong heating is set up over the lowered continent, leading to a marked thermal low pressure cell that develops between $30^{\circ} \mathrm{S}$ and $\sim 16^{\circ} \mathrm{S}$. In turns, this low drives the adjacent SPH northeastward. As a consequence of the strong pressure gradient set up between the thermal low and the SPH, strong winds blow equatorward at the margin of the two systems (Figure 5c). These meridional winds, stronger in the NOANDES case than in the CTL case, explain the stronger MWS depicted between $26^{\circ} \mathrm{S}$ and $12^{\circ} \mathrm{S}$ in January along the coast (Figure $4 \mathrm{c}$ ). On the contrary, weaker winds are simulated offshore, between $25^{\circ} \mathrm{S}$ and $30^{\circ} \mathrm{S}$, following the northward move of the SPH core. This latter change explains the zonal wind stress reduction depicted in Figure $4 \mathrm{c}$ at these latitudes.

[21] In July, the topographic barrier reduction makes the SPH moving eastward and merging within a giant highpressure belt at $32^{\circ} \mathrm{S}$, which links the Pacific Ocean to the Atlantic via the southern part of South America (Figure 5f). Consequently, weaker winds are simulated in NOANDES along the coast in July. This feature is robust, and has been first described by Richter and Mechoso [2006] with a different model. These signals are marked in NOANDES whereas differences between LOWANDES and CTL are less significant, suggesting that topography of the latter is not low 

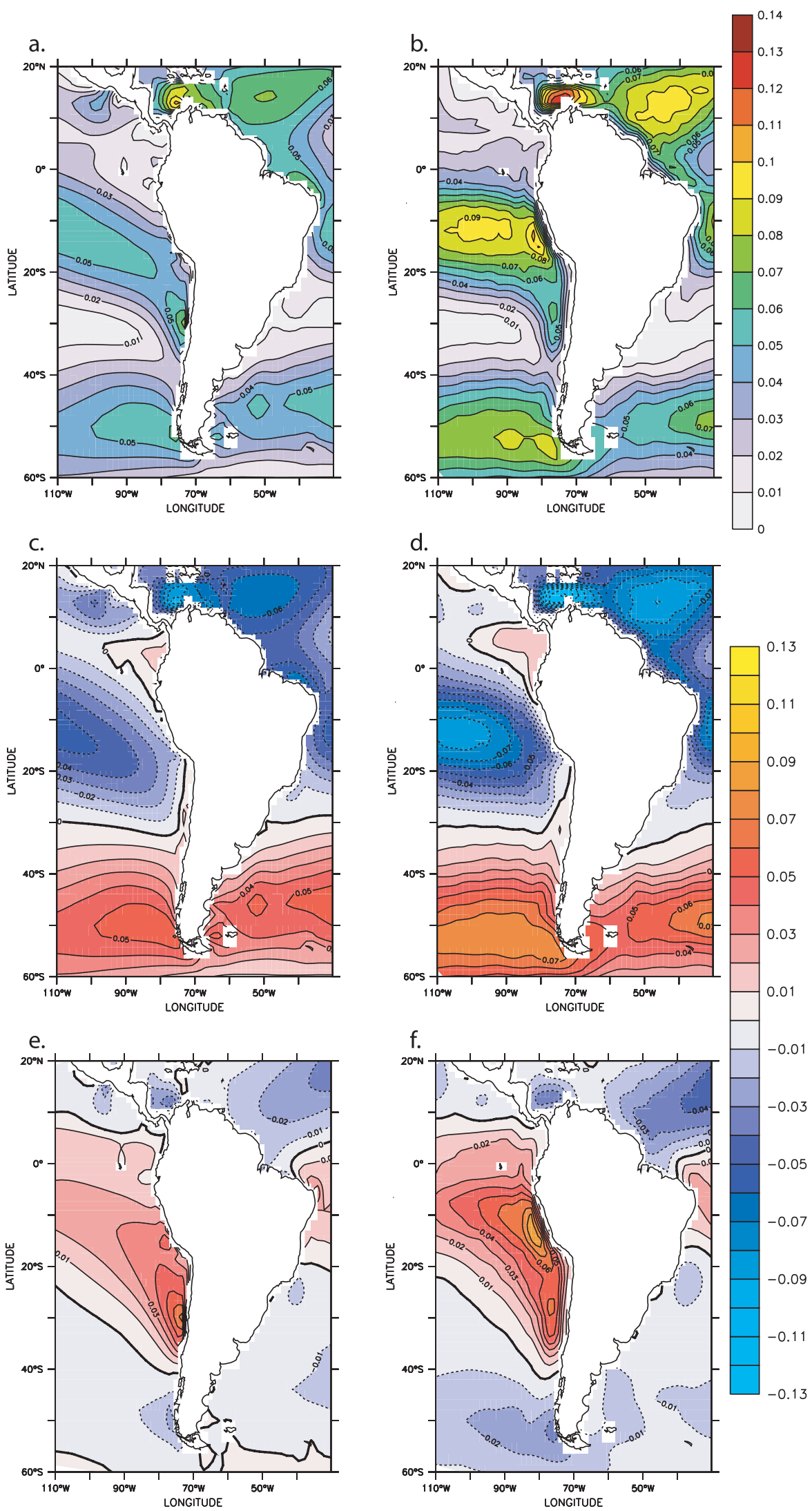

Figure 2. Annual wind stress fields for (a, c, and e) CTL experiment and (b, d, and f) NCEP reanalyses. Figures $2 \mathrm{a}$ and $2 \mathrm{~b}$ show the magnitude. Figures $2 \mathrm{c}$ and $2 \mathrm{~d}$ are zonal component. Figures $2 \mathrm{e}$ and $2 \mathrm{f}$ are meridional component. Units are Newton per square meters $\left(\mathrm{N} \mathrm{m}^{-2}\right)$. 


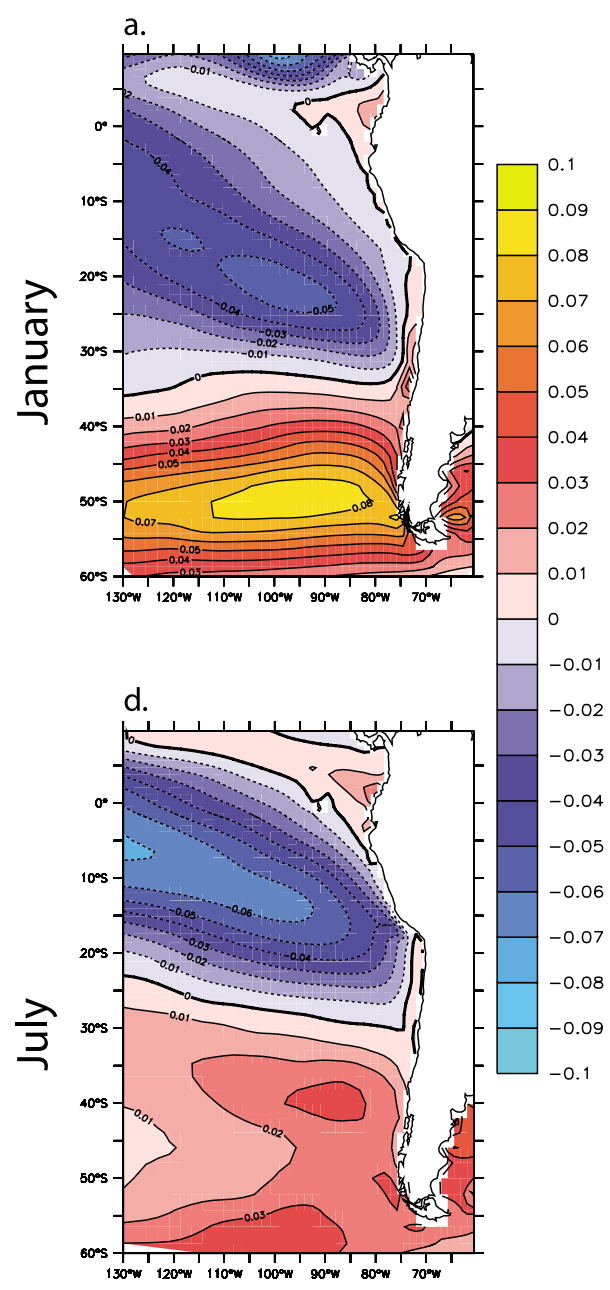

CTL
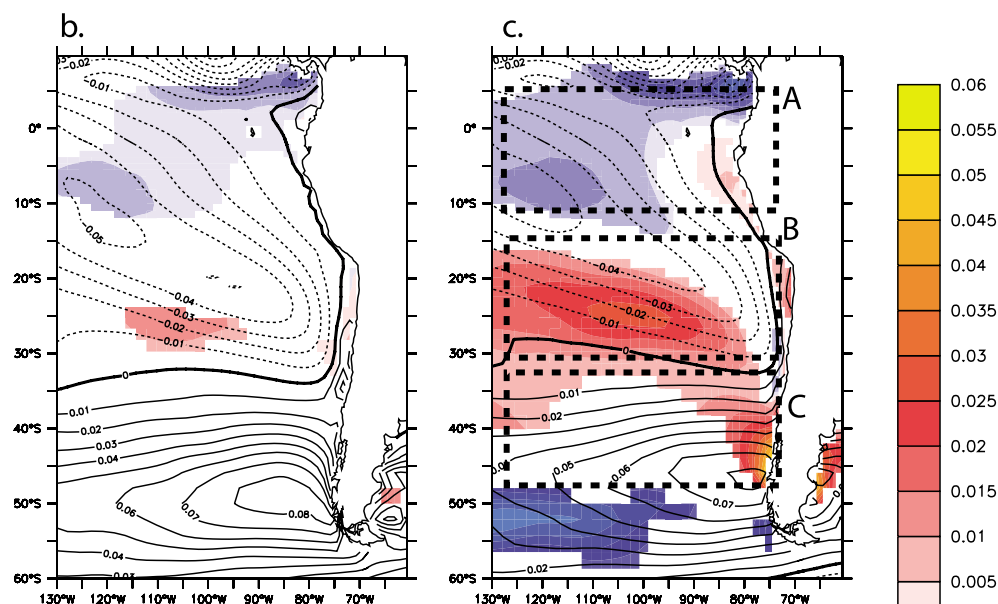

0.05

0.045

0.04

0.035

0.03

0.025

0.02

0.015

0.01

0.005

e.

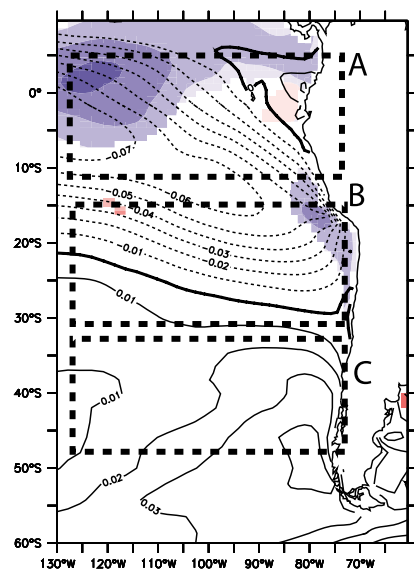

f.

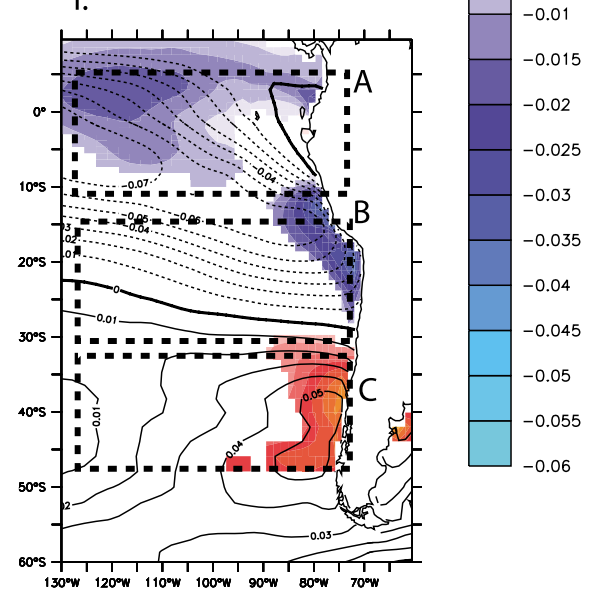

NOANDES-CTL

Figure 3. Seasonal zonal wind stress fields for (a, d) CTL and anomalies (b, e) LOWANDES-CTL and (c, f) NOANDES-CTL. Figures 3a-3c show Austral summer (January). Figures 3d-3f show Austral winter (July). Units are $\mathrm{N} \mathrm{m}^{-2}$. Regions discussed in the text are dashed.

enough to have important consequences on tropospheric dynamics.

\subsection{Oceanic Response}

[22] Here we analyze the simulated response of the ocean to the altered surface atmospheric patterns. We focus on SSTs and sea surface height (hereafter SSHs) signals (Figure 6). They are derived from a 20 year integration of the ROMS model, with the first decade used as a spin-up, and the second decade used to create a monthly "climatology" for SSHs and SSTs after a quasi-equilibrium in seasonal variations was reached. Since ROMS is forced at the open boundaries by present-day climatology (i.e., World Ocean Atlas 2001), the model is limited in its ability to represent changes in basinscale circulation that may have occurred under Cenozoic conditions (e.g., opened Panama isthmus). However, the model is well suited to investigate the impact of altered wind stress and heat flux on present-day oceanic circulation, thus providing useful insight on locally generated variability in
SSHs and SSTs under atmospheric patterns that existed prior to the Andean uplift.

[23] Ocean response to the CTL forcing depicts clearly the cold tongue along the south American coast and its northward extent in July (Figures 6a and 6d). SSHs values give insights concerning the dynamical structure of the ocean. It reveals clearly the South Pacific subtropical gyre, centered over the western edge of the domain. The Andes reduction makes the Pacific gyre shift slightly eastward both in July and January, as depicted by the zero SSHs isoline (Figures $6 \mathrm{~b}$ and $6 \mathrm{e}$ ). This corresponds to a direct forcing by the eastward shift of the SPH simulated by LMDz (Figure 5). In January, the gyre is also moved northward, in response to the northward shift of the zonal wind stress described earlier.

[24] SSTs response to the Andes reduction is also very clear. In January, a warming reaching up to $3^{\circ} \mathrm{C}$ is simulated offshore, between $25^{\circ} \mathrm{S}$ and $30^{\circ} \mathrm{S}$, adjacent to a $2^{\circ} \mathrm{C}$ cooling between $30^{\circ} \mathrm{S}$ and $35^{\circ} \mathrm{S}$ (Figure $6 \mathrm{c}$ ). This change is the consequence of the northward displacement of the SPH core and 

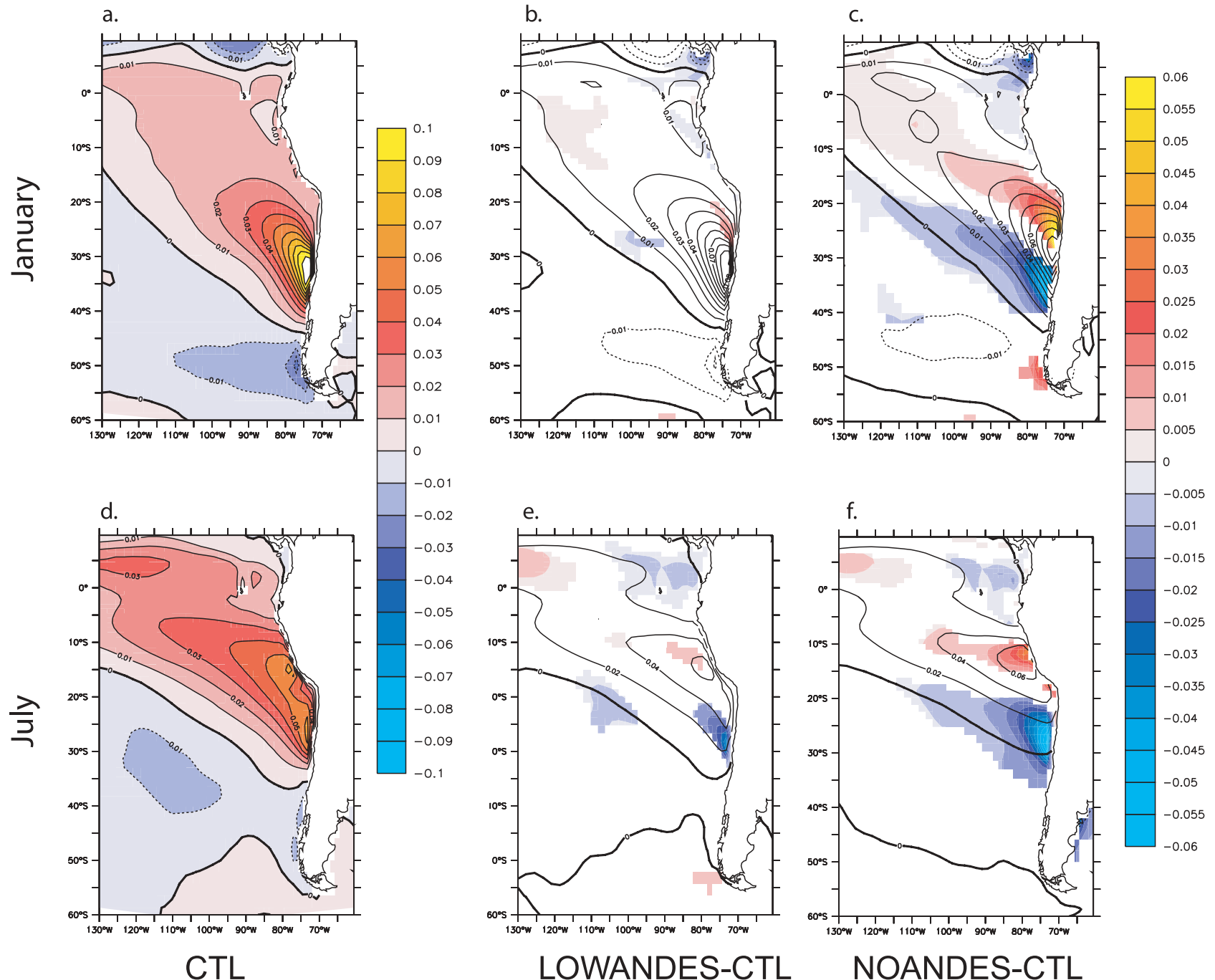

Figure 4. Same as Figure 3 but for meridional wind stress. Units are $\mathrm{N} \mathrm{m}^{-2}$.

associated wind patterns. Weaker winds between $25^{\circ} \mathrm{S}$ and $30^{\circ} \mathrm{S}$ leads to lower evaporation rate, lower latent heat release and higher SSTs. South of $30^{\circ} \mathrm{S}$, surface winds are strengthened and cool the ocean surface. Over a narrow area along shore, RNOANDES shows a decrease of SSTs between $30^{\circ} \mathrm{S}$ and $20^{\circ} \mathrm{S}$, consistent with the increase in upwelling favorable wind depicted in Figure 4c. In July, a strong increase in SSTs reaching $3{ }^{\circ} \mathrm{C}$ is simulated between $32^{\circ} \mathrm{S}$ and $20^{\circ} \mathrm{C}$ and extending from the coast out to $90^{\circ} \mathrm{W}$. This corresponds to a collapse of the cold tongue, clearly linked to the MWS decrease (Figure 4f), which is a consequence of the giant high-pressure belt induced by the topographic barrier lowering.

\section{Discussion}

\subsection{Role of the Uplift on HCS Evolution}

[25] Although there are several deep sea sediment cores available off the south American coast from Leg 202 of the Ocean Drilling Program [Tiedemann et al., 2007], those with reconstructed SSTs for the Neogene are north of $20^{\circ} \mathrm{S}$, and most of them too far northward to record the evolution of the HCS. Site $1237\left(\sim 16^{\circ} \mathrm{S}\right)$ is the only one to be at the same time close enough to the coast to capture the HCS signal and to provide published SSTs and biogenic paleoproductivity reconstructions for the late Miocene. Tiedemann et al. [2007] have highlighted that an increase in both biogenic paleoproductivity (biogenic opal) and eolian deposition (terrigenous) occurred after $\sim 8 \mathrm{Ma}$ at this site. A first step in the paleoproductivity increase is recorded between $10 \mathrm{Ma}$ and $5 \mathrm{Ma}$, [Tiedemann et al., 2007, Figure 9]. In the light of our modeling results, and with the evidences of a topographic uplift from $1500 \pm 500 \mathrm{~m}$ to $\sim 3500 \pm 500 \mathrm{~m}$ between $10 \mathrm{Ma}$ and $5 \mathrm{Ma}$ [Garzione et al., 2006, 2008], we suggest that this increase is due to the Andean uplift, whereas the second abrupt step recorded from $5 \mathrm{Ma}$ to the Quaternary is to be related to Mio-Pliocene global cooling.

\subsection{Sea Surface Temperature Signal}

[26] From our numerical experiments we can infer that the HCS has been significantly modified when the Andes 
a.

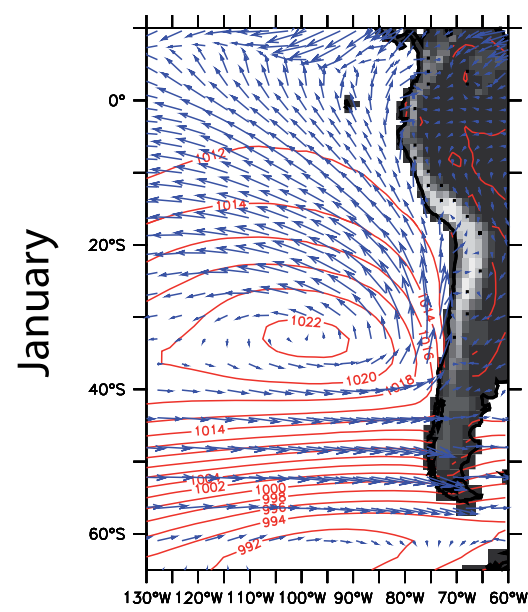

d.

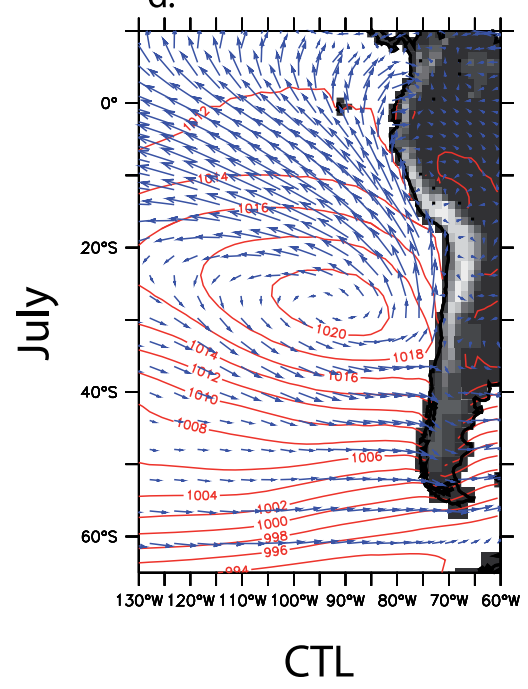

b.
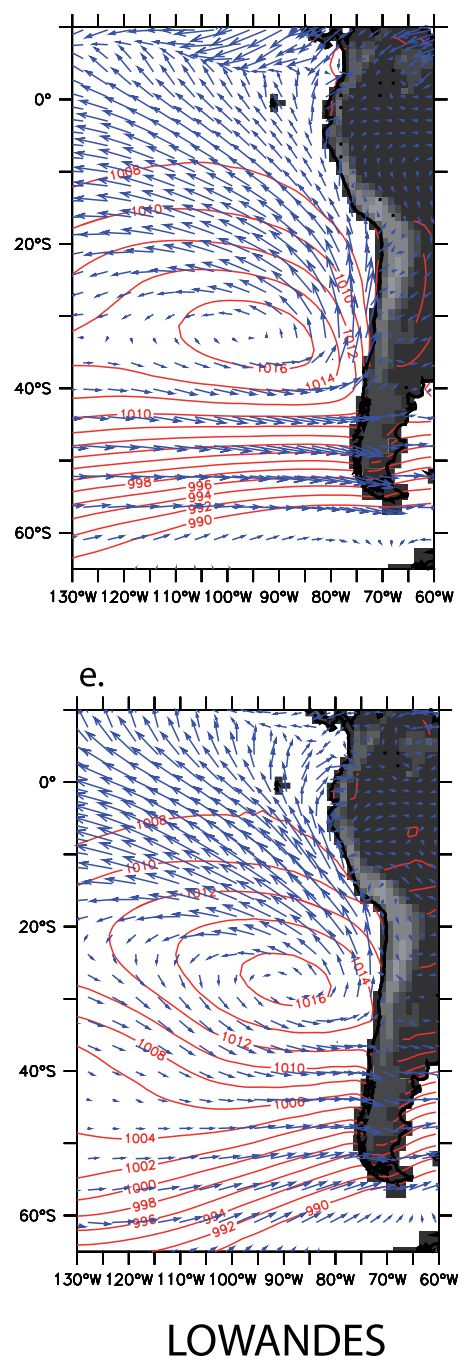

c.

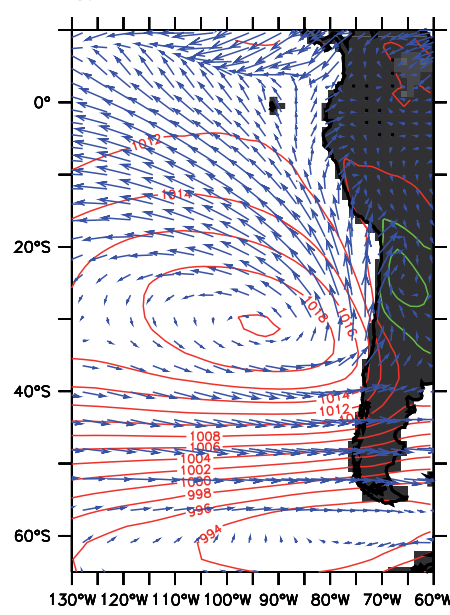

f.

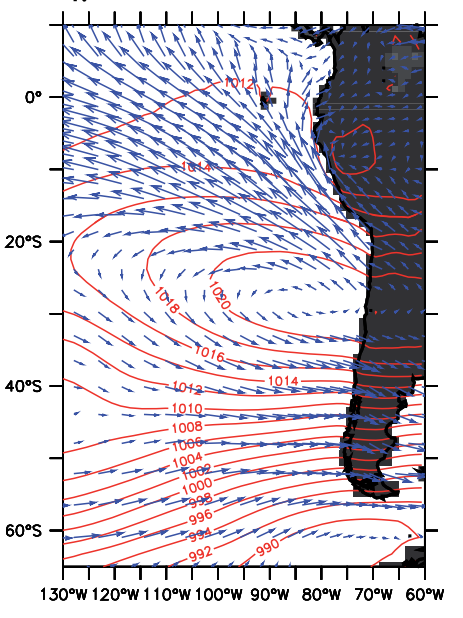

NOANDES

Figure 5. Seasonal sea level pressure fields and surface winds for (a, d) CTL, (b, e) LOWANDES, and $(c, f)$ NOANDES. Sea level pressure over areas of topography higher than $1000 \mathrm{~m}$ above sea level are not plotted for clarity. Figures 5a-5c show Austral summer (January). Figures 5d-5f show Austral winter (July). Vector units are meters per second, and isoline units are millibars.

uplifted. The uplift alone has led to an up to $3^{\circ} \mathrm{C}$ decrease of SSTs, and an overall southward shift of the South Pacific subtropical gyre. The SSTs change not only concerns the coastal area, as it reaches $110^{\circ} \mathrm{W}$ in January, and thereby suggesting a far-field influence of the uplift. Unfortunately, SSTs reconstructions at Site 1237 do not extend beyond $6 \mathrm{Ma}$. A decrease in SSTs is reconstructed between 3.6 and $2.4 \mathrm{Ma}$, and by comparing this record with the Benguela Current system off southwestern Africa, Tiedemann et al. [2007] suggest that the temperature drop is linked to a global cooling rather than to the Andes uplift, which would have played a role of secondary importance at that period. Indeed, regarding the paleotopographic history of the Andes, it is very likely that most of their present height was in place at $3.6 \mathrm{Ma}$ and that tectonics are not responsible for the Pliocene climate change recorded.
[27] For periods older than $6 \mathrm{Ma}$, our results suggest that the uplift shifted the tropospheric dynamics between the Pacific and the Atlantic from a zonally interconnected mode, with strong thermal pressure contrasts between Pacific ocean and the continent, to a mode including a physical separation of masses of air between the Pacific and the South American continent. Moreover, LOWANDES run, forced with a topography reduced by $\sim 50 \%$, shows rather small changes in the wind stress patterns compared to the present. This suggests that a $2500 \mathrm{~m}$ height has been sufficient to switch from a preAndes HCS to a modern-like HCS, and that this modification occurred before the Andes reached their modern height.

[28] We can infer that an older SST data set would record this shift, with a trend to lower SSTs in the regions where the $\mathrm{HCS}$ is reinforced (north of $25^{\circ} \mathrm{S}$ ), and higher SSTs where it is weakened (south of $25^{\circ} \mathrm{S}$ ). 

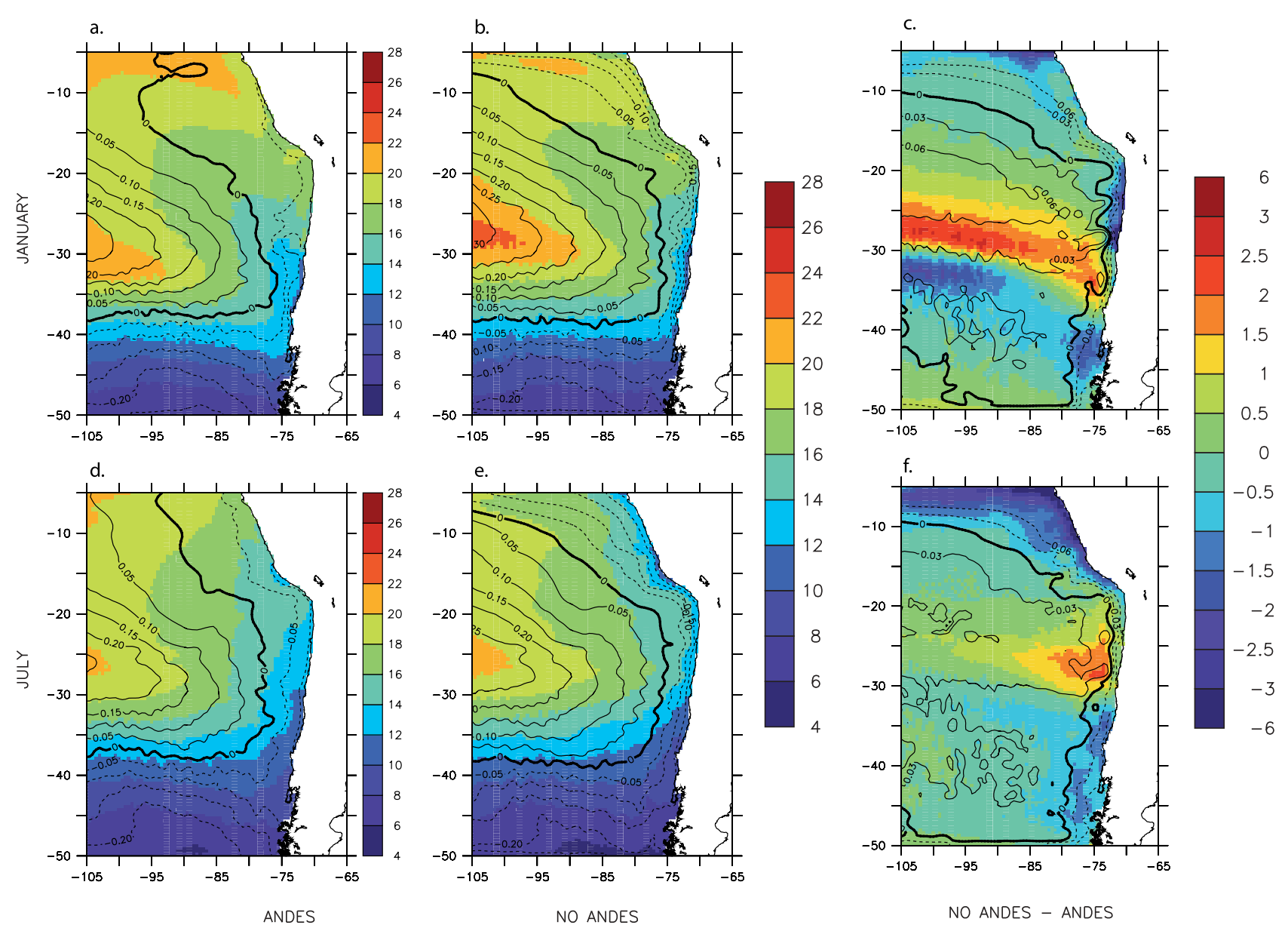

Figure 6. SSTs (color map) and SSHs (isolines) for (a, b, and c) January and (d, e, and f) July as simulated in RCTL and RNOANDES experiments. SST and SSH absolute values for RCTL (Figures 6a and 6d) and RNOANDES (Figures $6 \mathrm{~b}$ and 6e) and anomalies (RNOANDES-RCTL) between the two experiments (Figures 6c and 6f). Units are degrees Celsius for SSTs and meters for SSHs.

\subsection{Andean Uplift Signal Compared to Other Forcing Factors}

[29] As a consequence of the million year timescale of the uplift, the shift from a pre-Andes HCS to a modern-like HCS might have been overlapped with shorter-timescale mechanisms, as suggested by variations of reconstructed Holocene SSTs off Chile [Lamy et al., 2002]. Among these mechanisms, insolation forcing is prominent, with changes in the seasonal radiative balance driving the global meridional circulation [Walker and Schneider, 2005], and thus the relative positions of the SPH and the thermal low over the ocean and the continent. Modeling studies have shown that an increase in the Earth's obliquity (and an associated reduction in meridional insolation and sea level pressure gradients) leads to a decrease in tropical easterlies and near-surface winds around the SPH [Lee and Poulsen, 2005]. Recent works [Brown et al., 2008; Otto-Bliesner et al., 2006] have also suggested that the subtropical wind field patterns were reduced during the mid-Holocene, a period during which high-latitude insolation seasonality was stronger than present. Such orbital variations also occurred during the Cenozoic [Laskar et al., 2004] but their impact in a no-Andes context remain to be quantified, to assess if orbital variations would have amplified or counteracted the effect of the uplift during the Miocene. This point highlights the need for new designs of paleoclimate studies, as million year-scale and millennialscale studies for the early Neogene should now account for a different atmospheric circulation as a background forcing of the paleoclimatic record. This statement is true for other parts of the globe at the same latitude, as the Andes influence the global zonal wind patterns as well (not shown).

[30] Continental drift, i.e., opening of the Drake passage and closure of the Panaman seaway, likely have played a role on the HCS dynamics as well. Although focus has been set on their respective consequences for the Atlantic thermohaline circulation, and onset of the Antarctic Circumpolar current [Prange and Schulz, 2004; Schneider and Schmittner, 2006], the impact of these gateways on HCS evolution can be deduced from sensitivity modeling experiments. Lunt et al. [2008] online available material show that closure of the Panama isthmus led to a decrease of 1.5 to $2^{\circ} \mathrm{C}$ between $15^{\circ} \mathrm{S}$ and $30^{\circ} \mathrm{S}$, along shore of South America. Sijp and England [2004] model runs suggest a decrease in SSTs of no more than $1.5^{\circ} \mathrm{C}$, south of $35^{\circ} \mathrm{S}$ linked to the opening of Drake passage. 
Future studies will have to account for these changes in paleogeography, as well as paleotopography to better constrain HCS evolution.

\subsection{Feedbacks on the Climate System}

[31] SSTs have strong potential feedbacks on climate. At present, cold SSTs influence the rainfall patterns over the western edge of the Andes, and are considered as one of the reasons for the Atacama desert hyperaridity. Sedimentological studies have tried to decouple the physical impact of topography from the impact of ocean processes [Hartley et al., 2005]. It has been suggested that the Andes only played a role by developing a rain shadow on the continent (thus preventing moisture from the Amazon basin to reach the coast), but that the main triggers of the Miocene climate change over the Atacama Desert were the HCS intensification and the global cooling [Hartley, 2003]. Here, we show that the Andes directly influenced the HCS and associated SSTs patterns. These results suggest that the Andes have played a major role in the onset of the Atacama desert, via changes in the HCS. Our modeled SSTs will help future paleoclimate studies that will tackle the full understanding of Atacama desert history.

[32] The significant differences in oceanic SSTs and meridional shift of the subtropical gyre (as evidenced by SSHs) under surface atmospheric forcing pre-Andean and postAndean uplift hint at important feedback mechanisms between the ocean and the atmosphere. Our results therefore suggest that, in future uncoupled approaches, an iterative procedure should be used between the atmospheric and oceanic models to prescribed surface forcing (i.e., SSTs for the atmosphere and energy fluxes for the ocean). Alternatively, running a fully coupled ocean-atmosphere model would provide a complete description of atmospheric and oceanic variability under various paleoclimate scenario.

[33] This change in SSTs has also impacted evaporation rates along the whole South American coast. In a context of low Andes, evaporation and water vapor transport from the
Pacific ocean toward the continent can be crucial, especially for vegetation cover. Our atmospheric results, if confronted to paleovegetation data from South America, can help understanding paleoenvironmental evolution during the late Neogene. Future work, through collaboration with geologists, will include defining experiments with realistic paleotopography scenarios and a full coupling with an ocean model. An additional step forward in modeling will be to incorporate orbital configurations corresponding to key periods of the Cenozoic.

\section{Conclusion}

[34] We propose that the Neogene Andes uplift strongly modified the atmospheric circulation over the Pacific Ocean, which in turn changed the characteristics of the Humboldt Current system. We model a latitudinal shift of the wind stress system and strong changes in both coastal and basinscale SSTs patterns. An experiment run with intermediate Andes elevations shows little wind field differences with the control experiment, suggesting that an altitudinal threshold, allowing the HCS to shift to a modern-like structure, could have been reached before the Andes ended their uplift. Our quantifications of SSTs changes can be used for comparison with data sets that will surely be published in the following years for the Miocene, as well as to drive new modeling studies. They also open doors to constrain paleocirculation of the subtropical Pacific and to study the feedbacks of the uplift-induced SSTs changes on the continental hydrological cycle and paleoenvironments, which has never been done before.

[35] Acknowledgments. The LMDz numerical calculations were carried out on the supercomputers of the Centre de Calcul Recherche et Technologie, CEA, France. Calculation time was provided as a courtesy of the climate modeling team directed by Didier Paillard, at the LSCE, Gifsur-Yvette, France (UMR 1572 CEA/CNRS/UVSQ). Authors thank Gilles Ramstein for helpful comments and Daniel J. Lunt for helping to access his climate model experiments.

\section{References}

Alheit, J., and P. Bernai (1992), Effects of physical and biological changes on the biomass yield of the Humboldt Current ecosystem, in Large Marine Ecosystems: Patterns, Processes, and Yields, edited by K. Sherman, L. M. Alexander, and B. D. Gold, pp. 5368, Am. Assoc. for the Adv. of Sci., Washington, D. C.

Alpers, C., and G. Brimhall (1988), Middle Miocene climatic change in the Atacama Desert, northern Chile: Evidence from supergene mineralization at La Escondida, Geol. Soc. Am. Bull., 100(10), 1640-1656, doi:10.1130/ 0016-7606(1988)100<1640:MMCCIT>2.3. $\mathrm{CO} ; 2$.

Amiot, R., et al. (2008), Oxygen isotope compositions of phosphate from Middle MioceneEarly Pliocene marine vertebrates of Peru, Palaeogeogr. Palaeoclimatol. Palaeoecol., 264(1-2), 85-92, doi:10.1016/j.palaeo. 2008.04.001.

Bakun, A., and C. S. Nelson (1991), The seasonal cycle of wind-stress curl in subtropical eastern boundary current regions, J. Phys. Oceanogr.,
21(12), 1815-1834, doi:10.1175/1520-0485 (1991) $021<1815$-TSCOWS $>2.0$. CO 2

Barker, P. F., and E. Thomas (2004), Origin, signature and palaeoclimatic influence of the Antarctic Circumpolar Current, Earth Sci. Rev., 66(1-2), 143-162, doi:10.1016/j.earscirev. 2003.10.003.

Bartoli, G., et al. (2005), Final closure of Panama and the onset of Northern Hemisphere glaciation, Earth Planet. Sci. Lett., 237(1-2), 3344, doi:10.1016/j.eps1.2005.06.020.

Bigg, G. R. (2003), Wind-driven circulation of the ocean, in The Oceans and Climate, edited by G. R. Bigg, pp. 71-75, Cambridge Univ. Press, Cambridge, U. K.

Brown, J., et al. (2008), Modelling mid-Holocene tropical climate and ENSO variability: Towards constraining predictions of future change with palaeo-data, Clim. Dyn., 30(1), 19-36, doi:10.1007/s00382-007-0270-9.

Caviedes, C. N., and T. J. Fik (1992), The PeruChile eastern Pacific fisheries and climatic oscillation, in Climate Variability, Climate Change, and Fisheries, edited by M. H.
Glantz, pp. 355-376, Cambridge Univ. Press, Cambridge, U. K

Chaigneau, A., and O. Pizarro (2004), Mean surface circulation and mesoscale turbulent flow characteristics in the eastern South Pacific from satellite tracked drifters, J. Geophys. Res., 110, C05014, doi:10.1029/2004JC002628.

Conkright, M. E., R. A. Locarnini, H. E. Garcia, T. O'Brien, T. P. Boyer, C. Stephens, and J. I Antonov (2002), World Ocean Atlas 2001: Objective analyses, data statistics, and figures: CD-ROM documentation, Internal Rep. 17, 17 pp., NODC, Silver Spring, Md.

Curchitser, E. N., D. B. Haidvogel, A. J. Hermann, E. L. Dobbins, T. M. Powell, and A. Kaplan (2005), Multi-scale modeling of the North Pacific Ocean: Assessment and analysis of simulated basin-scale variability (1996-2003), J. Geophys. Res., 110, C11021, doi:10.1029/ 2005JC002902.

Fiechter, J., and A. M. Moore (2009), Interannual spring bloom variability and Ekman pumping in the coastal Gulf of Alaska, J. Geophys. Res. 114, C06004, doi:10.1029/2008JC005140. 
Garzione, C. N., et al. (2006), Rapid late Miocene rise of the Bolivian Altiplano: Evidence for removal of mantle lithosphere, Earth Planet. Sci. Lett., 241(3-4), 543-556, doi:10.1016/j.epsl.2005.11.026.

Garzione, C. N., et al. (2008), Rise of the Andes, Science, 320(5881), 1304-1307, doi:10.1126/ science.1148615.

Gregory-Wodzicki, K. M. (2000), Uplift history of the central and northern Andes: A review, Geol. Soc. Am. Bull., 112(7), 1091-1105, doi:10.1130/0016-7606(2000)112<1091: UHOTCA $>2.3 . \mathrm{CO} ; 2$.

Haidvogel, D. B., et al. (2000), Model evaluation experiments in the North Atlantic Basin: Simulations in nonlinear terrain-following coordinates, Dyn. Atmos. Oceans, 32(3-4), 239281, doi:10.1016/S0377-0265(00)00049-X.

Hartley, A. J. (2003), Andean uplift and climate change, J. Geol. Soc. London, 160, 7-10.

Hartley, A. J., G. Chong, J. Houston, and A. E. Mather (2005), 150 million years of climatic stability: Evidence from the Atacama Desert, northern Chile, J. Geol. Soc., 162, 421-424.

Hay, W. W., et al. (2002), The Late Cenozoic uplift: Climate change paradox, Int. J. Earth Sci., 91(5), 746-774, doi:10.1007/s00531002-0263-1.

Hoke, G. D., B. L. Isacks, T. E. Jordan, N. Blanco, A. J. Tomlinson, and J. Ramezani (2007), Geomorphic evidence for post-10 Ma uplift of the western flank of the central Andes $18^{\circ} 30^{\prime}-$ $22^{\circ} \mathrm{S}$, Tectonics, 26, TC5021, doi:10.1029/ 2006TC002082.

Hourdin, F., et al. (2006), The LMDZ4 general circulation model: Climate performance and sensitivity to parametrized physics with emphasis on tropical convection, Clim. Dyn., 27(7-8), 787-813, doi:10.1007/s00382-006-0158-0.

Houston, J., and A. J. Hartley (2003), The central Andean west-slope rainshadow and its potential contribution to the origin of hyper-aridity in the Atacama Desert, Int. J. Climatol., 23(12), 1453-1464, doi:10.1002/joc.938.

Ibaraki, M. (1990), Eocene through Pleistocene planktonic foraminifers off Peru, Leg 112 Biostratigraphy and paleoceanography, in Proceedings of the Ocean Drilling Program, Scientific Results, vol. 112, edited by E. Suess et al., pp. 239-262, Ocean Drill. Program, College Station, Tex.

Kalnay, E., et al. (1996), The NCEP/NCAR 40year reanalysis project, Bull. Am. Meteorol. Soc., 77(3), 437-471, doi:10.1175/15200477(1996)077<0437:TNYRP>2.0.CO;2.

Lamb, S., et al. (1997), Cenozoic evolution of the central Andes in Bolivia and northern Chile, Geol. Soc. Spec. Publ., 121(1), 237-264, doi:10.1144/GSL.SP.1997.121.01.10.
Lamy, F., C. Rühlemann, D. Hebbeln, and G. Wefer (2002), High- and low-latitude climate control on the position of the southern PeruChile Current during the Holocene, Paleoceanography, 17(2), 1028, doi:10.1029/ 2001PA000727.

Laskar, J., et al. (2004), A long-term numerical solution for the insolation quantities of the Earth, Astron. Astrophys., 428(1), 261-285, doi:10.1051/0004-6361:20041335.

Lee, S.-Y., and C. J. Poulsen (2005), Tropical Pacific climate response to obliquity forcing in the Pleistocene, Paleoceanography, 20, PA4010, doi:10.1029/2005PA001161.

Lunt, D. J., et al. (2008), Closure of the Panama Seaway during the Pliocene: Implications for climate and Northern Hemisphere glaciation, Clim. Dyn., 30(1), 1-18, doi:10.1007/ s00382-007-0265-6.

Otto-Bliesner, B. L., et al. (2006), Last Glacial Maximum and Holocene climate in CCSM3, J. Clim., 19(11), 2526-2544, doi:10.1175/ JCLI3748.1.

Pagani, M., et al. (2005), Marked decline in atmospheric carbon dioxide concentrations during the Paleogene, Science, 309(5734), 600-603, doi:10.1126/science. 1110063 .

Picard, D., T. Sempere, and O. Plantard (2008), Direction and timing of uplift propagation in the Peruvian Andes deduced from molecular phylogenetics of highland biotaxa, Earth Planet. Sci. Lett., 271(1-4), 326-336, doi:10.1016/j.epsl.2008.04.024.

Prange, M., and M. Schulz (2004), A coastal upwelling seesaw in the Atlantic Ocean as a result of the closure of the Central American Seaway, Geophys. Res. Lett., 31, L17207, doi:10.1029/2004GL020073.

Richter, I., and C. R. Mechoso (2006), Orographic influences on subtropical stratocumulus, J. Atmos. Sci., 63(10), 2585-2601, doi:10.1175/JAS3756.1.

Schneider, B., and A. Schmittner (2006), Simulating the impact of the Panamanian seaway closure on ocean circulation, marine productivity and nutrient cycling, Earth Planet. Sci. Lett., 246(3-4), 367-380, doi:10.1016/ j.epsl.2006.04.028.

Shchepetkin, A. F., and J. C. McWilliams (2005) The regional oceanic modeling system (ROMS): A split-explicit, free-surface, topographyfollowing-coordinate oceanic model, Ocean Modell., 9(4), 347-404, doi:10.1016/j.ocemod. 2004.08 .002

Sijp, W., and M. England (2004), Effect of the Drake Passage throughflow on global climate, J. Phys. Oceanogr., 34(5), 1254-1266, doi: $10.1175 / 1520-0485(2004) 034<1254$ : EOTDPT>2.0.CO;2
Snyder, M. A., L. C. Sloan, N. S. Diffenbaugh, and J. L. Bell (2003), Future climate change and upwelling in the California Current, Geophys. Res. Lett., 30(15), 1823, doi:10.1029/ 2003GL017647.

Summerhayes, C. P., et al. (1992), Upwelling Systems: Evolution Since the Early Miocene, Geol. Soc. Spec. Publ., 64, 519 pp.

Taylor, K. E., et al. (2000), The sea surface temperature and sea-ice concentration boundary conditions for AMIP II simulations, Rep. 60 , Program for Clim. Model Diagnosis and Intercomparison, Livermore, Calif.

Thiel, M., et al. (2007), The Humboldt Current system of northern and central Chile: Oceanographic processes, ecological interactions and socioeconomic feedback, Oceanogr. Mar Biol., 45, 195-344.

Tiedemann, R., et al. (2007), Leg 202 synthesis Southeast Pacific paleoceanography, in Proceedings of the Ocean Drilling Program, Scientific Results, vol. 202, edited by R. Tiedemann et al., pp. 1-56, Ocean Drill. Program, College Station, Tex.

Trenberth, K. E., et al. (1990), The mean annual cycle in global ocean wind stress, $J$. Phys. Oceanogr., 20(11), 1742-1760, doi:10.1175 1520-0485(1990)020<1742:TMACIG $>2.0$. $\mathrm{CO} ; 2$.

Tsuchi, R. (1997), Marine climatic responses to Neogene tectonics of the Pacific Ocean seaways, Tectonophysics, 281(1-2), 113-124, doi:10.1016/S0040-1951(97)00163-7.

Walker, C. C., and T. Schneider (2005), Response of idealized Hadley circulations to seasonally varying heating, Geophys. Res. Lett. 32, L06813, doi:10.1029/2004GL022304.

$\mathrm{Xu}, \mathrm{H}$., et al. (2004), Effects of the Andes on eastern Pacific climate: A regional atmospheric model study, J. Clim., 17(3), 589-602 doi:10.1175/1520-0442(2004)017<0589:EO$\mathrm{TAOE}>2.0 . \mathrm{CO} ; 2$.

J. Fiechter, Department of Ocean Sciences, University of California, 1156 High St., Santa Cruz, CA 95064, USA.

P. Sepulchre, Laboratoire des Sciences du Climat et de 1'Environnement, IPSL, CEA, UVSQ, CNRS, F-91191 Gif-sur-Yvette CEDEX, France. (pierre.sepulchre@1sce.ipsl.fr)

L. C. Sloan and M. Snyder, Department of Earth and Planetary Sciences, University of California, 1156 High St., Santa Cruz, CA 95064, USA. 